La liebre amenazada Lepus flavigularis prefiere establecer

sus sitios de alimentación y descanso en potreros con presencia de ganado

\title{
Endangered jackrabbit Lepus flavigularis prefers to establish its feeding and resting sites on pasture with cattle presence
}

\author{
Alma Luna-Casanova ${ }^{1}$, Tamara Rioja-Paradela ${ }^{2}$, Laura Scott-Morales ${ }^{1}$ and Arturo Carrillo-Reyes ${ }^{3}$
}

\begin{abstract}
1 Facultad de Ciencias Forestales, Universidad Autónoma de Nuevo León. Carretera Panamericana km $145 \mathrm{~s} / \mathrm{n}, 67710$. Linares, Nuevo León, México. Email: alma.luna6@gmail.com (AL-C) Iscott@fcf.uanl.mx (LS-M).

${ }^{2}$ Sustentabilidad y Ecología Aplicada, Universidad de Ciencias y Artes de Chiapas. Libramiento Norte Poniente s/n, 29039. Tuxtla Gutiérrez, Chiapas, México. Email: tamararioja@gmail.com (TR-P).

${ }^{3}$ Oikos: Conservación y Desarrollo Sustentable, A. C. Calle Bugambilias No. 5, Colonia Bismark, 29267. San Cristóbal de las Casas, Chiapas, México. Email: acarrillo@oikos.org.mx (AC-R).

* Corresponding author
\end{abstract}

Lepus flavigularis Wagner 1844 (Tehuantepec jackrabbit), a species endemic to southern Oaxaca in Mexico, and is currently considered as the jackrabbit in greatest danger of extinction worldwide. In the locality of Santa María del Mar in Oaxaca, it inhabits open pastures, sharing habitat with domestic cattle (Bos taurus). We hypothesize that L. flavigularis prefers to establish its feeding and resting sites in pastures where cattle are present. Understanding interspecific relationships is of great importance to the establishment of appropriate management plans. We record radio-tagged and no radio-tagged jackrabbits that established their resting and feeding sites on pastures with presence and absence of cattle and a compositional analysis of habitat preference was conducted. This paper reports for the first time the preference of $L$. flavigularis to establish feeding $(K=0.8010, P=0.0020)$ and resting sites $(K=0.6605, P=0.016)$ in the pasture with the presence of cattle. Selection of these sites could be attributed to the fact that the presence of cattle can function as an alarm system against possible predators, while the cattle grazing could itself promote palatable species of Poaceae that form part of the diet of this leporid. This information is key to the establishment of future management plans for both species and their ecosystem. A long-term study is required in order to determine the feasibility of cattle and jackrabbit cohabitation. We propose that an efficient rotational grazing program, could contribute to the conservation of this jackrabbit population.

Lepus flavigularis Wagner 1844 (Liebre de Tehuantepec), es una especie endémica del sur de Oaxaca, México. Actualmente considerada como la liebre en mayor peligro de extinción en todo el mundo. En Santa María del Mar, en Oaxaca, la liebre habita en pastizales abiertos, compartiendo su hábitat con el ganado doméstico (Bos taurus); nuestra hipótesis es que $L$. flavigularis prefiere establecer sus sitios de alimentación y de descanso en potreros donde el ganado está presente. Se registró el número de liebres radio-marcadas y sin marcar que establecieron sus sitios de alimentación y de descanso en potreros con presencia y ausencia de ganado bovino y se llevó a cabo un análisis composicional de la preferencia de hábitat. L. flavigularis prefiere establecer sus sitios de alimentación $(K=0.8010, P=$ $0.0020)$ y sitios de descanso $(K=0,6605, P=0,016)$ en potreros con presencia de ganado. La selección de estos sitios se puede atribuir al hecho de que la presencia de ganado puede funcionar como un sistema de alarma contra posibles depredadores, mientras que el pastoreo del ganado podría en sí promover especies palatables de Poaceae que forman parte de la dieta local de este leporido. Esta información es clave para la creación de planes de manejo para ambas especies y su ecosistema. Se requiere un estudio a largo plazo para determinar la viabilidad de la cohabitación de la liebre y el ganado. Proponemos que un programa de rotación de ganado eficiente podría contribuir a la conservación de esta población de liebres.

Key words: habitat; grazing; livestock; management; predators; Tehuantepec jackrabbit.

(c) 2016 Asociación Mexicana de Mastozoología, www.mastozoologiamexicana.org 


\section{Introduction}

Lepus flavigularis is a species endemic to southern Tehuantepec Isthmus in Oaxaca, Mexico, catalogued as endangered by the IUCN Red List of Threatened Species (Cervantes et al. 2016) and currently considered the lagomorph species in the greatest danger of extinction worldwide, due to anthropogenic activities such as agriculture, urban development and illegal hunting (Lorenzo et al. 2015; Rioja-Paradela et al., 2012). This species is a regulator of plant populations in its ecosystem, exerting an influence on the vegetation structure and on germoplasm dispersion (Cervantes and González 1996; Farías et al. 2006). However, the relationships between this species and other herbivores that share its habitat, such as cattle, remain poorly understood. HernándezGuevara (2015) conducted a microhistological analysis in the same study area and reported an overlap of $85 \%$ between the diet items of L. flavigularis and Bos taurus in Santa María del Mar, Oaxaca. Other studies show a clear trophic competition between leporids and ruminants such as cattle (Mysterud and Mysterud 2000; Smith et al. 2004), resulting in a negative effect on leporids populations (Carpio et al. 2014; Hulbert and Andersen 2001). However, some evidence show that the ecological separation between grazing herbivores is a common phenomenon (Jarman 1974), and leporids and cattle can coexist and obtain mutual benefits while not exceed the grazing capacity (Karmiris et al. 2005; Karmiris and Nastis 2010); for example, at long-time scales the cattle can improve forage quality and foraging efficiency leading to facilitation for leporids (Kuijper et al. 2008). Carrillo-Reyes et al. (2012) state that, in Santa María del Mar, L. flavigularis is mainly found in the same open pastures used by the local inhabitants as grazing areas for their cattle. We hypothesize that $L$. flavigularis prefers to establish its feeding and resting sites in pastures where cattle are present. Understanding interspecific relationships is of great importance to the establishment of appropriate management plans, since these relationships have profound implications for the population dynamics of the species involved (Steen et al. 2005; Kuijper et al. 2008; Karmiris and Nastis 2010). The present paper aims to elucidate this relationship for the first time and thus to contribute to the generation of the fundamental knowledge necessary to develop a management plan for L. flavigularis and its habitat.

\section{Material and methods}

The study area is located at southern Tehuantepec isthmus, in the state of Oaxaca, Mexico, bordering Laguna Superior and the Pacific Ocean. The population of L. flavigularis is found concentrated in the locality of Santa María del Mar, in the municipality of Juchitán de Zaragoza, Oaxaca, within the coordinates $16^{\circ} 14^{\prime} 12.53^{\prime \prime} \mathrm{N},-94^{\circ} 57^{\prime} 58.72^{\prime \prime} \mathrm{W}$ and $16^{\circ} 12^{\prime} 15.83^{\prime \prime} \mathrm{N},-94^{\circ} 45^{\prime} 39.82^{\prime \prime} \mathrm{W}$. L. flavigularis population distributed in Santa María del Mar is the most isolated population (Rico et al. 2007), but also the more densely populated of the four remaining (Rioja-Paradela et al. 2012).

The area is approximately $14.33 \mathrm{~km}^{2}$ and presents an average elevation of $9 \mathrm{~m}$ (Figure 1 ; RiojaParadela et al. 2012). Climate in the area is warm subhumid with summer rains (Aw0), according to the Köppen classification. Annual average temperature is $22{ }^{\circ} \mathrm{C}$, with a minimum monthly temperature above $18^{\circ} \mathrm{C}$. Annual average precipitation is $1,078.4 \mathrm{~mm}$ (Servicio Meteorológico Nacional 2015). Vegetation present throughout the habitat of L. flavigularis mainly comprises open pasture characterized by the presence of grass (Jouvea pilosa) and cacti such as Opuntia tehuantepecana and $O$. decumbens distributed throughout a series of pastures used to feed and protect domestic cattle (B. taurus) (Carrillo-Reyes et al. 2012; Hernández-Guevara 2015).

Area is covered by pastures in low floodable zones and dunes that display periodic movements throughout the year (Vargas 2000). Currently there is no rotational grazing program in study area. The movement of cattle between pastures is performed based on the immediate needs of owners of pastures and livestock. Pasture burns are rare in the area.

We selected 10 pastures distributed along L. flavigularis habitat in Santa María del Mar, from which five have presence of cattle (16.2 \pm 6.01 cows per pasture) and five have no cattle presence. 
Pastures selection was based on jackrabbits distribution and the permission granted by owners. Cattle presence was determined by direct observation of cows in pastures during monitoring periods. All pastures were located next to each other; mean size of pastures was $11.24 \mathrm{ha}$. The number of cows on each pasture was constant throughout the study, and no rotational grazing was made while this research was conducted. Cattle moved freely within each pasture.

Floristic composition, aerial coverage (percentage of the ground covered by the aerial canopy of a plant), density, frequency and the importance value index (sum of relative density, relative frequency and relative aerial coverage) of the species at open pasture vegetation were recorded. For this, six linear transects each of $50 \mathrm{~m}$ in length were randomly established, three in pastures with cattle and three in pastures without cattle (Carrillo-Reyes et al. 2010; Hernández-Guevara 2015). The average distance between each transect was $680 \mathrm{~m}$. Along each transect, five circular plots of $1 \mathrm{~m}^{2}$ were established at distances of $10 \mathrm{~m}$ apart to measure all the variables mentioned above for the herbaceous plants, while one single circular plot of $12.62 \mathrm{~m}^{2}$ was established for the shrubs (Carrillo-Reyes et al. 2010; Rioja et al. 2011; Hernández-Guevara 2015). Floristic composition was determined to species level, using the vegetation list previously established by Rioja (2008) and (Carrillo-Reyes 2009). Vegetal coverage, density and frequency were calculated and they relative values obtained (Elzinga et al. 2001) to obtain the importance value index applying the methodology proposed by Di Stefano and Newell (2008).

A total of 22 adult jackrabbits (10 males and 12 females) were captured and radio-tagged during March 2014 throughout the entire L. flavigularis habitat at the study area. Jackrabbits were considered adult or mature when they presented an approximate weight of $1.8 \mathrm{~kg}$ or more and a length of at least $55.6 \mathrm{~cm}$ (Vorhies and Taylor 1933; Rioja et al. 2011). The jackrabbits were captured during the day using a fishing net known commonly as a "manga" (40 m long and $1 \mathrm{~m}$ in height) placed in pasture areas with a group of 10 people employed to surround the area in front of the net and run towards it scaring the hares into the net. This method allowed the rapid and safe capture of the jackrabbits (Carrillo-Reyes et al. 2010; Rioja et al. 2011). Each captured specimen was placed in a cloth bag and its weight and basic morphological measurements (total length, tail length, foot length, ear length) recorded. The sex of each individual was determined by external morphological characteristics in addition to its age class. Each captured jackrabbit was marked with a radio transmitter for subsequent telemetry (Telenax ${ }^{\mathrm{TM}}$, model TX-35/24, battery of 24 months, $35 \mathrm{gr}$, frequency $150 \mathrm{Mhz}$, with sensor of activity/inactivity and mortality). The jackrabbits were released at the same site of capture and in a direction unhindered by direct obstacles (Carrillo-Reyes et al. 2010).

Two sessions of monitoring were conducted between March (dry season) and September (rainy season) of 2014. Each session of monitoring had a maximum duration of ten days. The jackrabbits were radio-located and monitored by direct observation, using portable receivers (Telenax TM TRX1000) and a portable, folding three-element Yagi antenna (Rioja et al. 2011). Furthermore, to increase the number of registered jackrabbits, five fixed observation sites were selected throughout the study area, from which monitored pastures were visible. These observation sites were located in key areas from which it was possible to observe jackrabbits in the pastures with and without cattle (Rioja et al. 2011). In order to avoid influencing the behavior of jackrabbits, observation was conducted from distances of 50 to $100 \mathrm{~m}$. During monitoring, jackrabbits continued eating, resting and interacting socially. Once an individual radio-tagged or no radio-tagged was observed, the time (hours and minutes) was recorded and the Universal Transversal Mercator (UTM) coordinates subsequently obtained using a manual GPS unit once the jackrabbit had moved away from the site. It was registered whether the jackrabbits were resting or eating in pastures with or without the presence of cattle. Monitoring was carried out between 6:00 - 10:00 hrs and between 17:00 - 20:00 hrs; these were time periods when jackrabbits were more active and visibility allow to observe individuals from a safe distance. Records of no radio-tagged jackrabbits were considered as independent when were obtained with at least 24 hours apart on the same site, to reduce temporal dependence between records (Norris et al. 2010). Analysis of data normality were realized using Shapiro-Wilks normality test (Shapiro and Wilk 1965). Results determined nonparametric analysis must were performed. 
Comparison of vegetation aerial coverage and importance value index between pastures with and without cattle was conducted using a Mann-Whitney $U$ test (Dickinson Gibbons and Chakraborti 2003). Same test was used to find significant differences $(P<0.05)$ in the establishment of feeding and resting sites for $L$. flavigularis between pastures with and without cattle.

In addition, a compositional analysis of habitat preference was conducted using the Wilks Lambda (Aebischer et al. 1993), a MANOVA that enables contrasting the availability of both pasture types (with and without cattle) per unit area with the number of recordings of jackrabbits in feeding and resting sites in each pasture type. For this specific analysis, it was considered that the habitat used corresponded in all cases to open pasture, according to previous studies on this species (Carrillo-Reyes et al. 2010, 2012; Rioja et al. 2011). We assume the existence of two types of available resource: pastures with cattle and pastures without cattle. Availability of every pasture type was calculated as proportion of each type through all monitoring area. All statistical analyses were performed with the software R and Rstudio (R Core Team 2015; RStudio Team 2015), using the packages "base" and "adehabitat" (Calenge 2006).

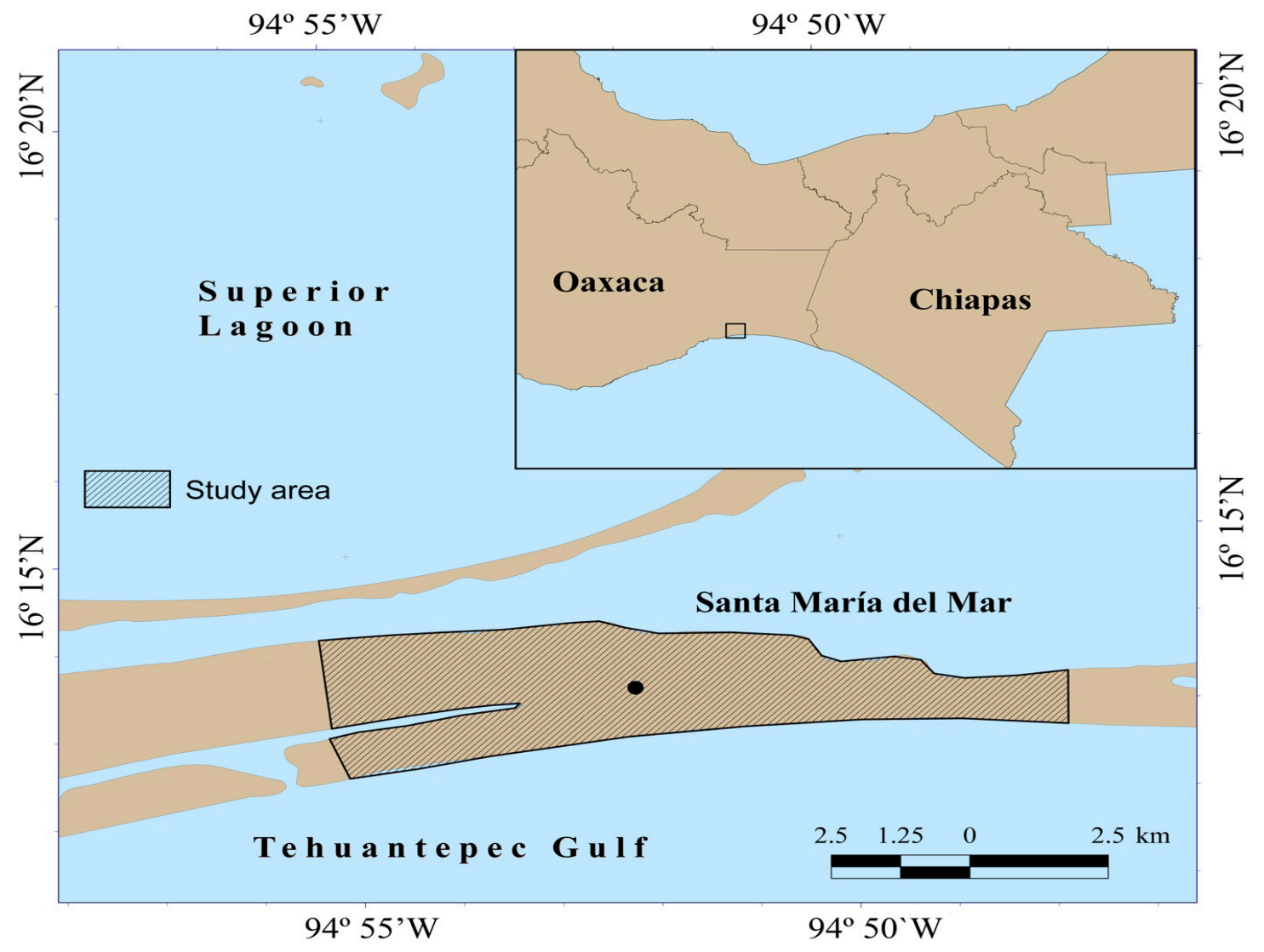

Figure 1. Study Area.

\section{Results}

A total of 84 individual records of tagged jackrabbits and 153 of untagged jackrabbits were achieved. Jackrabbits were observed eating in $68.78 \%$ of global records, and reposing or resting in $27.80 \%$ of records. The remaining records correspond to jackrabbits observed not performing any of these activities; in these cases, they were grooming themselves or moving between sites. When records between two pastures types were analyzed, $75 \%$ were from jackrabbits eating and $25 \%$ were from jackrabbits resting for pastures with cattle. In pastures without cattle jackrabbits were observed eating in $66 \%$ of records and resting in $34 \%$ of records. 
The total coverage of herbaceous plants was $16.16 \%$ and that of shrubs was $6.66 \%$ in pastures without cattle, while in those with cattle these values were $26.37 \%$ and $1.91 \%$, respectively. In pastures without cattle, the herbaceous plants of greatest importance value index were Bouteloua aristidoides (Kunth) Griseb. (123.93), B. repens (Kunth) Scribn. \& Merr. (53.99) and Jouvea pilosa (J. Presl) Scribn. (35.99), while the shrubs with greatest importance value index were Bursera glabrifolia (139.83), Acacia cornígera (77.19) and Cylindropuntia rosea (68.59). In pastures with cattle, the herbaceous plants of greatest importance value index were Amaranthus scariosus Benth. (49.47), B. aristidoides (Kunth) Griseb. (48.22) and Waltheria preslii Walp. (45.65), while the shrubs with greatest importance value index were B. glabrifolia (103.22), Opuntia fragilis (Nutt.) Haw. (51.98) and O. decumbens Salm-Dyck (38.86). Results do not show significant differences between vegetation with and without cattle (herbaceous plants: coverage $\mathrm{W}=161$, $P=0.723$, importance value index $\mathrm{W}=184, P=0.365$; shrubs: coverage $\mathrm{W}=860, P=$ 0.277 , importance value index $\mathrm{W}=126, P=0.587$ ).

Results show a significant difference on establishment of feeding ( $\mathrm{W}=240, P=$ $0.01403)$ and resting sites ( $W=93, P=0.03218)$ between pastures with and without cattle. Additionally, compositional analysis of preference indicated that $L$. flavigularis prefers to establish its feeding $(K=0.8010, P=0.0020)$ and resting $(K=0.6605, P=$ $0.016)$ sites in pastures with presence of cattle.

\section{Discussion}

No significant differences were found between the characteristics of the vegetation present in the pastures with and without cattle; however, the results indicate a clear preference of $L$. flavigularis for feeding and resting in pastures with the presence of cattle. In pastures without cattle, we recorded species with a high importance value index present in the local diet of $L$. flavigularis, such as $B$. aristidoides and B. repens (Hernández-Guevara 2015), but in the pastures with cattle we recorded species that also form part of the diet of this leporid and are only found in this pasture type, such as Gomphrena decumbens and Stipa eminens (Hernández-Guevara 2015; Hernández et al. Unpublished data). It is likely that the cattle promote these species growth through the establishment of seedlings in their dung (Malo and Suarez 1996; Kuijper et al. 2008). Herbaceous plants consumed by this lagomorph in pastures without cattle are also present in pastures with cattle, as confirmed by Hernández-Guevara (2015) who report an overlap of $85 \%$ of items in the diet of both herbivores in this population.

It is known that the jackrabbits are more vulnerable to predation if adequate vegetal coverage is not present (Carrillo-Reyes et al. 2012; Smith et al. 2005; Rioja 2008; Carrillo-Reyes et al. 2012). However, no significant differences were found in the coverage of herbaceous plants and shrubs between pastures with and without cattle. It is probable that L. flavigularis prefer pastures with cattle because they do not need to spend so much energy on vigilance against predators and can invest more time in feeding and resting. In this population, adults, juveniles and young of $L$. flavigularis are preyed upon by different animals, including feral dogs (Canis familiaris), reptiles such as the boa (Boa constrictor), whip snake (Masticophis mentovarius), western lyre snake (Trimorphodon biscutatus), coyote (Canis latrans), grey fox (Urocyon cinereoargenteus) and birds of prey such as the hook-billed kite (Chondrohierax uncinatus), common black hawk (Buteogallus anthracinus), roadside hawk (Rupornis magnirostris) and the red-tailed hawk (Buteo jamaicensis; Carrillo-Reyes 2009; Carrillo-Reyes et al. 2010, 2012; Rioja-Paradela et al. 2008, 2011; Vargas 2000).

It is possible that the presence of the cattle acts as an alarm system against the danger of predators. Some authors consider that the species develop different strategies in the face of predators; for example, the group strategy known as the "hypothesis of many eyes" that allows a reduction in individual vigilance by taking advantage of the combined vigilance of other individuals (Powell 1974; Dehn 1990; Lima 1995; Mendl and Held 2001). Being prey animals, fear motivates cattle to be constantly vigilant in order to escape from potential predators as coyote (Grandin 2007; Moran and 
Doyle 2015) by startling, baulking and fleeing (Klindworth et al. 2003). Harassment by predators may result in agitation and reduction of movement areas of cattle (Grandin 1999). Welp et al. (2016) reported cattle vigilance is increased and foraging behaviors decreased when a predator stimuli (wolf) are present; contrariwise, vigilance decreases when another herbivorous stimuli are present (Kluever et al. 2009). The coexistence of groups can provide a certain defense against possible predators and improve the overall efficacy of the vigilance (Lima and Eneldo 1990). For this reason, the fact that the detection of potential predators of $L$. flavigularis may be more effective in the company of cattle, considered as a possible explanation for the observed pasture preference, since the alarm behavior of cattle in the face of danger will be immediately apparent to the jackrabbit, thus facilitating detection and reaction by the leporid.

Our results suggest that, as with other leporids, L. flavigularis can live with cattle as long as the carrying capacity of the habitat is not exceeded at Santa María del Mar (Karmiris et al. 2005; Kuijper et al. 2008; Karmiris and Nastis 2010). However, a longterm study is required that focuses on carrying capacity of pastures, as well as the management to which the cattle are subjected in the study area, in order to determine the long-term feasibility of such cohabitation. This information is key to enable the establishment of a plan of management for both species and their ecosystem (RiojaParadela and Carrillo-Reyes 2014).

Actually, in Santa María del Mar locality pasture burns are an uncommon activity. This is a clear advantage in the establishment of a management program when compared to other L. flavigularis populations as that distributed in Montecillo Santa Cruz (Farías et al. 2006; Farías and Fuller 2009). At that locality the field is covered by anthropogenic burning to induce growth of green forage; when burned, grassy habitat without overstory turned into bare habitat with negligible cover and almost no herbaceous food for jackrabbits (Farías and Fuller 2009). Avoid burning should be promoted among landowners. Both, avoid burning and an efficient rotational grazing, could contribute to the conservation of this jackrabbit population.

\section{Acknowledgements}

Authors thank the people of Santa María de Mar, Oaxaca, México for the assistance provided during fieldwork. Thanks also go to CONACYT for providing the grant, and to the anonymous reviewers who helped to improve this manuscript.

\section{References}

Aebischer, N. J., P. A. Robertson, and R. E. Kenward. 1993. Compositional analysis of habitat use from animal radio-tracking data. Ecology 74:1313-1325.

Calenge, C. 2006. The package "adehabitat" for the R software: A tool for the analysis of space and habitat use by animals. Ecological Modelling 197:516-519.

Carpio, A. J., J. Guerrero-Casado, L. Ruiz-Aizpurua, J. Vicente, and F. S. Tortosa. 2014. The high abundance of wild ungulates in a Mediterranean region: is this compatible with the European rabbit? Wildlife Biology 20:161-166.

Carrillo-Reyes, A. 2009. Uso del hábitat de la liebre de Tehuantepec (Lepus flavigularis) en Santa María del Mar, Oaxaca. El Colegio de la Frontera Sur. San Cristóbal de las Casas, México.

Carrillo-Reyes, A., C. Lorenzo, E. J. Naranjo, M. Pando, and T. Rioja. 2010. Home range dynamics of the Tehuantepec Jackrabbit in Oaxaca, Mexico. Revista Mexicana de Biodiversidad 81:143-151.

Carrillo-Reyes, A., C. Lorenzo, T. Rioja-Paradela, E. Naranjo, and M. Pando. 2012. Uso de hábitat de la liebre en peligro de extinción, Lepus flavigularis: implicaciones para su conservación. Therya 3:113-125.

Cervantes, F., and F. González, F. 1996. Los Conejos y Liebres Silvestres de México. Ecología y Conservación del Conejo Zacatuche y su Hábitat. Universidad Autónoma de México y Fondo de Cultura Económica. Ciudad de México, México. 
Cervantes, F., C. Lorenzo, V. Farías, and J. Vargas. 2016. Lepus flavigularis. The IUCN Red List of Threatened Species 2008: e.T11790A3306162.

Denn, M. M. 1990. Vigilance for predators: detection and dilution effects. Behaviour ecology and sociobiology 26:337-342.

Dickinson Gibbons, J., and S. Chakraborti. 2003. Nonparametric statistical inference, 1st edition. Marcel Dekker. New York, EE. UU.

Di Stefano, J., And G. R. Newell. 2008. Diet selection by the swamp wallaby (Wallabia bicolor): feeding strategies under conditions of changed food availability. Journal of Mammalogy 89:1540-1549.

Elzinga, C. L., D. W. Salzer, J. W. Willoughby, and J. P. GibBs. 2001. Monitoring plant and animal populations. Blackwell Science, Inc. Malden, EE. UU.

Farías, V., AND T. Fuller. 2009. Native vegetation structure and persistence of endangered Tehuantepec jackrabbits in a neotropical savanna in Oaxaca, México. Biodiversity and Conservation 18:1963-1978.

Farías, V., T. K. Fuller, F. A. Cervantes, and C. Lorenzo. 2006. Home range and social behavior of the endangered Tehuantepec jackrabbit (Lepus flavigularis) in Oaxaca, Mexico. Journal of Mammalogy 87:748-756.

Grandin, T. 2007. Livestock Handling and Transport, 3rd edition. CABI editions. Wallingford, United Kindom.

Grandin, T. 1999. Safe handling of large animals. Occupational Medicine 14:195-212.

Hernández-Guevara, L. 2015. Competencia alimentaria entre Lepus flavigularis, un lepórido en peligro de extinción, y el ganado en el sur del Istmo de Tehuantepec, Oaxaca. Universidad Juárez del Estado de Durango. Gómez Palacio, México.

Hulbert, I. A., And R. Andersen. 2001. Food competition between a large ruminant and a small hindgut fermentor: the case of the roe deer and mountain hare. Oecologia 128:499-508.

JARMAN, P. J. 1974. The social organisation of antelope in relation to their ecology. Behaviour 48:215-266.

Karmiris, I. E., Z. Koukoura, and G. Christodoulou. 2005. Use of alpine ranges by brown hare (Lepus europaeus) and livestock in central Greece. Competition or facilitation? XXVIIth Congress of the International Union of Game Biologists. Hannover, Germany.

KaRmiRIS, I. E., AND A. S. NAStis. 2010. Diet overlap between small ruminants and the European hare in a Mediterranean shrubland. Central European Journal of Biology 5:729-737.

Klindworth, D., R. Greenall, and J. Campbell. 2003. CowTime Guidelines: For Milk Harvesting. Dairy Research and Development Corporation. Melbourne, Australia.

Kluever, B. M., L. D. Howery, S. W. Breck, And D. L. Bergman. 2009. Predator and heterospecific stimuli alter behaviour in cattle. Behavioural Processes 81:85-91.

KuiJPer, D.P. J., P. Beek, S. E. van Wieren, AND J. P. Bakker. 2008. Time-scale effects in the interaction between a large and a small herbivore. Basic and Applied Ecology 9:126-134.

LımA, S. L. 1995. Back to the basics of anti-predatory vigilance: the group size effect. Animal Behaviour 49:11-20.

Lima, S. L., AND L. M. Eneldo. 1990. Behavioral decisions made under the risk of predation: a review and prospects. Canadian Journal of Zoology 68:619-640.

Lorenzo, C. M., T. M. Rioja-Paradela, and A. Carrillo-Reyes. 2015. State of knowledge and conservation of endangered and critically endangered lagomorphs worldwide. Therya 6:11-30.

Malo, J. E., AND F. SuARez. 1996. Cistus ladanifer recriment-not only fire, but also deer. Acta Oecologica 17:55-60.

Mendl, M., And S. Held. 2001. Loving in groups: An evolutionary perspective. Pp. 7-19 in Social Behavior in Farm Animals (Keeling, J. L., and H.W. Gonyou, eds.). CABI Publishing. Oxfordshire, United Kindom.

Moran, J., AND R. Doyle. 2015. Cow Talk. CSIRO Publishing. Melbourne, Australia.

Mysterud, A., AND I. Mysterud. 2000. Okologiske effekter av husdyrbeiting i utmark: III. Pavirkning pa mindre pattedyr, fugler og virvellose dyr. Fauna Oslo 53:106-116.

Norris, D., F. Michalski, AND C. A. Peres. 2010. Habitat patch size modulates terrestrial mammal activity patterns in Amazonian forest fragments. Journal of Mammalogy 91:551-560. 
PoweLL, G. V. 1974. Experimental analysis of the social value of flocking by starlings (Sturnus vulgaris) in relation to predation and foraging. Animal Behaviour 22:501-505.

R Core Team. 2015. R: A Language and Environment for Statistical Computing. R Foundation for Statistical Computing. Vienna, Austria.

Rico, Y., Lorenzo, C., González-Cózatl, F., and E. Espinoza. 2007. Phylogeography and population structure of the endangered Tehuantepec jackrabbit (Lepus flavigularis): implications for conservation. Conservation Genetics 9: 1467-1477.

Rioja-Paradela, T., A. Carrillo-Reyes, and C. Lorenzo. 2012. Análisis de población viable para determinar el riesgo de extinción de la liebre de Tehuantepec (Lepus flavigularis) en Santa María del Mar, Oaxaca. Therya 3:137-150.

Rioja-Paradela, T. M. 2008. Comportamiento reproductivo de la liebre de Tehuantepec (Lepus flavigularis) en su hábitat. El Colegio de la Frontera Sur. San Cristóbal de las Casas, México.

Rioja-Paradela, T. M., and A. Carrillo-Reyes. 2014. Desarticulación entre políticas públicas para la conservación de la vida silvestre y la mitigación de la pobreza: el caso de la liebre de Tehuantepec (Lepus flavigularis) y pueblos indígenas del sureste de Oaxaca, México. Pp. 175-204 in Gestión territorial y manejo de recursos naturales: fauna silvestre y sistemas agropecuarios (Medina-Sansón, L., C. Tejeda-Cruz, A. Carrillo-Reyes, and T. Rioja-Paradela, eds.). Universidad Autónoma de Chiapas. Tuxtla Gutiérrez, México.

Rioja, T., C. Lorenzo, E. Naranjo, L. Scott, and A. Carrillo-Reyes. 2011. Breeding and parental care in the endangered Tehuantepec jackrabbit (Lepus flavigularis). Western North American Naturalist 71:56-66.

RStudio Team. 2015. RStudio: Integrated Development Environment for R (Versión 0.99.893). Boston, U.S.A.

Servicio Meteorológico Nacional. 2015. Normales climatológicas Estación 00020048 - Juchitán de Zaragoza, Oaxaca. Comisión Nacional del Agua. Ciudad de México, México.

ShapiRo, S. S., AND M. B. Wilk. 1965. An analysis of variance test for normality (complete samples). Biometrika 52:591-611.

Smith, R. K., N. V. Jenning, A. Robinson, and S. Harris. 2004. Conservation of European hares (Lepus europaeus) in Britain: Is increasing habitat heterogeneity in farmland the answer? Journal of Applied Ecology 41:1092-1102.

Smith, R. K., N. V. Jennings, F. Tataruch, K. Hackländer, and S. Harris. 2005. Vegetation quality and habitat selection by European hares Lepus europaeus in a pastural landscape. Acta Theriologica 50:391-404.

Steen, H., A. Mysterud, And G. Austrheim. 2005. Sheep grazing and rodent populations: evidence of negative interactions from a landscape scale experiment. Oecologia 143:357-364.

VARGAS, J. 2000. Distribución, abundancia y hábitat de la liebre endémica Lepus flavigularis (Mammalia: Lagomorpha). Universidad Nacional Autónoma de México. Ciudad de México, México.

Vorhies, C. T., and W. P. Taylor. 1933. The life histories and ecology of Jack Rabbits, Lepus alleni and Lepus californicus ssp., in relation to grazing in Arizona. CALS Publications Archive. The University of Arizona. Tucson, U.S.A.

Welp, T., J. Rushen, D. Kramer, M. Festa-Bianchet, and A. M. de Passillé. 2016. Vigilance as a measure of fear in dairy cattle. Applied Animal Behaviour Science 87:1-13.

Summited: March 30, 2016

Review: April 27, 2016

Accepted: May 20, 2016

Associated editor: Sergio Solari 